\title{
PLANT GROWTH AND SOLUTE ACCUMULATION AND DISTRIBUTION IN TWO SORGHUM GENOTYPES, UNDER NACI STRESS
}

\author{
CLAUDIVAN FEITOSA DE LACERDA ${ }^{1}$, JOSÉ CAMBRAIA ${ }^{2}$, MARCO ANTONIO \\ OLIVA CANO ${ }^{3}$ AND HUGO ALBERTO RUIZ ${ }^{4}$
}

Departmento de Biologia Geral, Universidade Federal de Viçosa, Viçosa, MG, 36571-000, Brazil

\begin{abstract}
Seedlings of two sorghum (Sorghum bicolor (L.) Moench) genotypes with differential tolerance to salinity were exposed to 0 and $100 \mathrm{mM} \mathrm{NaCl}$, gradually added in increments of $25 \mathrm{mM}$ every 12 hours, in nutrient solution. Seven days after starting the salt treatment the growth of the shoot and root system and the inorganic and organic solutes contents were determined. Salinity reduced the dry matter yield and length of the shoot and root system in both sorghum genotypes, specially in the sensitive one. In general, it was observed an increase in $\mathrm{Na}^{+}$and $\mathrm{Cl}^{-}$transfer to the shoot, in $\mathrm{Na}^{+}$and $\mathrm{Cl}^{-}$accumulation and in the $\mathrm{Na}^{+} / \mathrm{Cl}^{-}$ratio but a decrease in the $\mathrm{K}^{+}$and $\mathrm{Ca}^{2+}$ transfer to shoot and in the $\mathrm{K}^{+}$and $\mathrm{Ca}^{2+}$ contents in the shoot, always with higher intensity in sensitive genotype. Apparently, the tolerance to high saline concentrations in sorghum seems to be related to the genotype ability to avoid accumulation of harmful levels of $\mathrm{Na}^{+}$and $\mathrm{Cl}^{-}$and, or to maintain adequate levels of $\mathrm{K}^{+}$and $\mathrm{Ca}^{2+}$, specially in the shoot. The soluble carbohydrates and amino acids constituted together over $98 \%$ of the total organic solutes and showed the greatest absolute increase in concentration during saline stress. Probably, the soluble carbohydrates were the most important organic solutes to contribute to the osmotic adjustment in the leaves and the amino acids in the roots. Under saline stress there was an expressive increase in proline contents, specially in the oldest leaves of sensitive genotype. The proline contents, however, even under salt stress, did not reach the levels of other organic solutes. Contrary to the general acceptance, proline does not seem to have an important role in the mechanism of salt tolerance, at least for these genotypes and under the experimental conditions applied here.
\end{abstract}

ADDITIONAL INDEX TERMS: Salinity, salt stress, salt accumulation, organic solutes accumulation, Sorghum bicolor.

\section{CRESCIMENTO DA PLANTA E ACÚMULO E DISTRIBUIÇÃO DE SOLUTOS EM DOIS GENÓTIPOS DE SORGO, SUBMETIDOS A ESTRESSE COM NACI}

RESUMO - Plântulas de dois genótipos de sorgo (Sorghum bicolor (L.) Moench) com tolerância diferencial à salinidade foram expostas a 0 e $100 \mathrm{mM}$ de $\mathrm{NaCl}$, aplicado gradualmente em incrementos de $25 \mathrm{mM}$, a cada 12 horas, em solução nutritiva. Após 7 dias de tratamento salino foram determinados o

Received: 2/7/2001 - Accepted: 11/11/2001

1. Agronomist, D.S., Dept. de Ciência do Solos /UFC, Fortaleza, CE, 60021-970; Corresponding author: e-mail: cfeitosa@ufc.br

2. Full professor, Ph.D., Dept. de Biologia Geral /UFV, Viçosa, MG; CNPq researcher.

3. Full professor, Dr. rer nat, Dept. de Biologia Vegetal /UFV, Viçosa, MG; CNPq researcher.

4. Full professor, D.S., Dept. de Solos /UFV, Viçosa, MG; CNPq researcher. 
crescimento da parte aérea e das raízes e os teores de solutos inorgânicos e orgânicos. A salinidade reduziu a produção de matéria seca e o comprimento tanto da parte aérea como do sistema radicular nos dois genótipos de sorgo, principalmente no genótipo sensível. Observou-se, de modo geral, aumento nas transferências de $\mathrm{Na}^{+}$e de $\mathrm{Cl}^{-}$para a parte aérea, nos acúmulos de $\mathrm{Na}^{+}$e $\mathrm{Cl}^{-}$e na relação $\mathrm{Na}^{+} / \mathrm{K}^{+}$mas redução nas transferências de $\mathrm{K}^{+}$e de $\mathrm{Ca}^{2+}$ para a parte aérea e nos teores de $\mathrm{K}^{+}$e $\mathrm{Ca}^{2+}$ na parte aérea, sempre com maior intensidade no cultivar sensível. Aparentemente, a tolerância a altas concentrações salinas em sorgo parece estar relacionada com a capacidade do genótipo evitar o acúmulo de íons como $\mathrm{Na}^{+}$e $\mathrm{Cl}^{-}$e, ou manter níveis adequados de íons como $\mathrm{K}^{+}$e $\mathrm{Ca}^{2+}$, principalmente na parte aérea. Os carboidratos solúveis e aminoácidos constituíram juntos acima de $98 \%$ do total de solutos orgânicos e apresentaram os maiores aumentos absolutos em concentração durante o estresse salino. Provavelmente, os carboidratos solúveis e os aminoácidos foram os solutos orgânicos que mais contribuíram para o ajuste osmótico nas folhas e raízes, respectivamente. Sob estresse salino observou-se, também, expressivo aumento nos teores de prolina, especialmente nas folhas mais velhas do genótipo sensível. No entanto, estes teores, mesmo nas plantas estressadas, foram muito inferiores aos de outros solutos orgânicos. Ao contrário do que tem sido geralmente estabelecido, prolina não parece ter um importante papel no mecanismo de tolerância ao estresse salino, pelo menos para estes genótipos e sob as condições experimentais utilizadas neste estudo.

TERMOS ADICIONAIS PARA INDEXAÇÃO: Salinidade, estresse salino, acúmulo de sais, acúmulo de solutos orgânicos, Sorghum bicolor.

\section{INTRODUCTION}

Many species of higher plants, including most crops, are subjected to growth inhibition under high- $\mathrm{NaCl}$ conditions. The salt-induced inhibition of plant growth, so-called salt stress, is caused not only by osmotic effects on water uptake but also by variable effects on plant cell metabolism under salt stress. While the first component can bring about water deficit, the excess of an specific ion can cause toxicity and, or induce nutritional disorders (Greenway and Munns, 1980).

The interpretation of the saline effects at the whole plant level is quite complex and still rather incomplete. The accumulation of salts in mature leaves, for instance, can affect their growth, change their metabolism and reduce the production of photosynthates. However, before the salt concentration reaches stressing levels in the leaf, the plant can experience growth reduction, due to water deficit (Munns and Termaat, 1986). It must be pointed out also that the saline stress on mature leaves can affect the development of new leaves.

Glycophytes, in general, when exposed to high salt concentration seem to be able to reduce the accumulation of $\mathrm{Na}^{+}$and $\mathrm{Cl}^{-}$in the leaves and to increase the concentration of certain osmotically active organic compounds, such as proline, glycine betaine and soluble carbohydrates, among others. These solutes, which accumulate mainly in the cytoplasm, contribute to the osmotic adjustment, protecting cell structures and functions and also constitute a source metabolic energy (Serrano and Gaxiola, 1994). In some species, however, a correlation between organic solutes accumulation and tolerance to salt stress was not observed (Greenway and Munns, 1980). Also, it is interesting to observe that sometimes correlation between organic solute accumulation and salt tolerance to high salt concentration has been inferred based in just a simple increase of solute contents. Higher solute accumulation, however, does not mean, necessarily, a direct relationship between this accumulation and plant growth (Maggio et al, 1997).

The objective of this work was to evaluate the effects of high $\mathrm{NaCl}$ concentration on the plant growth, on the inorganic solutes transfer to shoot and on the accumulation and distribution of inorganic solutes $\left(\mathrm{Cl}^{-}, \mathrm{Na}^{+}, \mathrm{K}^{+}, \mathrm{Ca}^{2+}\right.$ and $\left.\mathrm{Mg}^{2+}\right)$ and organic solutes (proline, soluble 
carbohydrates, amino acids and betaine), in order to better understand the mechanism of saline tolerance in two sorghum genotypes

\section{MATERIAL AND METHODS}

Two genotypes of forage sorghum (Sorghum bicolor (L) Moench), one salt tolerant (ST87-11-ST88-03-ST89-02-ST90-01-ST91-03-

VIT91-B-Ca92B) and the other salt sensitive (5163Ca84-B1-Ca87-B2-BCa89) were studied. These genotypes were gently provided by the Empresa Pernambucana de Pesquisa Agropecuária (IPA), Recife, Pernambuco, Brazil.

Seeds, selected for size and shape, were surface sterilized with $2 \%$ sodium hypochlorite for 10 minutes. After extensive rinses with running water and distilled water, the seeds were germinated in rolls of neutral $\mathrm{pH}$ "germtest" paper.

Seven days old seedlings, selected for uniform size, were transferred, in groups of four, to 2.6 L polyethylene pots with Clark's nutrient solution (with double $\mathrm{P}$ concentration), $\mathrm{pH} 5.5$ (Clark, 1975), in the absence and presence of 100 $\mathrm{mM} \mathrm{NaCl}$. The saline treatment consisted of adding $\mathrm{NaCl}$ to the nutrient solution to obtain concentration increments of $25 \mathrm{mM}$ every 12 hours, until reaching the final concentration of 100 $\mathrm{mM}$.

All experiments were conducted in a growth chamber with controlled temperature (25 $\pm 3^{\circ} \mathrm{C}$ ), under photosynthetically active radiation of $230 \mu \mathrm{mol} \mathrm{m}^{-2} \mathrm{~s}^{-1}$ and a photoperiod of $16 \mathrm{~h}$. The nutrient solutions were continuously aerated and the $\mathrm{pH}$ daily adjusted to 5.5 by adding $\mathrm{HCl}$ or $\mathrm{NaOH}$.

Seven days after the beginning of salt treatment, the plants were harvested, washed in running water and in demineralized water, divided into shoot and roots, and the length of the root system, of the first internode and the total length of the stem were measured.

In samples of root system, stems plus sheaths, leaf blades with apparent salt toxicity symptoms $\left(3^{\text {rd }}\right.$ and $4^{\text {th }}$ leaves, from the top of the plant) and leaf blades without salt toxicity symptoms ( $2^{\text {nd }}$ leaf, from the top of the plant) the inorganic solutes $\left(\mathrm{Na}^{+}, \mathrm{K}^{+}, \mathrm{Ca}^{2+}, \mathrm{Mg}^{2+}\right.$ and $\left.\mathrm{Cl}^{-}\right)$and organic solutes (proline, betaine, soluble carbohydrates, and total free amino acids) contents were determined.

In a parallel and similar experiment, as previously described, seven days old seedlings were exposed to $100 \mathrm{mM} \mathrm{NaCl}$, added in increments of $25 \mathrm{mM}$. At 0,4 and 8 days after the beginning of $\mathrm{NaCl}$ treatment, samples were collected to evaluate the root dry matter yield and to determine ion contents in the shoot. Data were used to estimate the net ion transfer rates to the shoot according to the equation proposed by Salim and Pitman (1983):

The plant material, dried in oven at $80^{\circ} \mathrm{C}$ to constant weight, was finely ground and digested with a nitric-perchloric mixture. In the mineral extract the contents of $\mathrm{Na}^{+}$and $\mathrm{K}^{+}$were determined by emission spectrophotometry and of $\mathrm{Ca}^{2+}$ and $\mathrm{Mg}^{2+}$ by atomic absorption spectrophotometry (Allan, 1969).

Chloride was extracted by stirring finely ground dried samples with $0.1 \mathrm{M} \mathrm{NaNO}_{3}$ for 30 minutes. After extract clarification with activated coal, it was added $13.2 \mathrm{mM} \mathrm{Hg}(\mathrm{SCN})_{2}$ in methanol and $20.2 \%(\mathrm{w} / \mathrm{v}) \mathrm{Fe}\left(\mathrm{NO}_{3}\right)_{3}(4+1)$ and the absorbance determined at $460 \mathrm{~nm}$ (Gaines et al., 1984).

Betaine was extracted by stirring finely ground dried samples with demineralized water at $100^{\circ} \mathrm{C}$ for 1 hour. The extract was treated with a small portion of AG $50 \mathrm{Wx} 8,200-400$ mesh resin (Ladyman et al., 1983), filtered and betaine content determined after reaction with $\mathrm{KI}_{-} \mathrm{I}_{2}$ at $365 \mathrm{~nm}$, as recommended by Storey and Wyn Jones (1977).

Proline was extracted from fresh plant material in $5 \mathrm{~mL}$ of $3 \%(\mathrm{w} / \mathrm{v})$ sulfosalicylic acid and determined by the method described by Bates et al. (1973).

Soluble carbohydrates were extracted according to official method of analysis of the Official Association of Analytic Chemists (A.O.A.C.) (Horwitz, 1975) and the total soluble 
carbohydrates contents were determined by the method of anthrone (Hodge and Hofreiter, 1962).

Free amino acids were extracted in a water-toluene mixture $(15: 0,03 ; \mathrm{v} / \mathrm{v})$, at $30^{\circ} \mathrm{C}$ for 60 minutes (Weimberg et al., 1982) and determined after reaction with ninhydrin reagent (Moore and Stein, 1948).

All experiments followed a factorial arrangement, in randomized blocks, with three replicates. Data were subjected to an analysis of variance (ANOVA) and the means compared by Tukey's test at $5 \%$ of probability.

\section{RESULTS AND DISCUSSION}

\section{Effect of Salinity on Plant Growth}

The salt stress caused reductions of 30 and $40 \%$ in shoot and of 19 and $30 \%$ in root dry matter yields in the tolerant and sensitive genotypes, respectively (Table 1). The tolerant genotype yielded larger amount of dry matter than the sensitive genotype only in the shoot, regardless of the saline treatment. After the saline treatment, the shoot/roots dry matter ratio reduced 10 and $18 \%$ in the tolerant and sensitive genotypes, respectively. The largest shoot/root dry matter ratio and the smallest reduction of this ratio after saline treatment observed in the tolerant genotype suggest that this plant characteristic could be an important tolerance indicator of salt stress, at least in sorghum. In rice varieties, a positive correlation between the shoot/roots ratio and the tolerance to $\mathrm{NaCl}$ also has been found (Lutts et al., 1996). According to Shannon et al. (1994), however, under field conditions, the decrease in the shoot/roots ratio under saline conditions, on the opposite, allows a better use of the soil moisture and of nutrients, which may have a beneficial effect on plant growth.

TABLE 1 - Effect of $\mathrm{NaCl}$ treatment on the shoot and root dry matter yield and on the shoot/roots ratio in two sorghum genotypes.

$\mathrm{NaCl}$

$(\mathrm{mM})$

Dry matter yield $\left(\mathrm{g} \mathrm{pot}^{-1}\right)^{1}$

\section{Salt Tolerant}

\begin{tabular}{cccc}
\hline & Shoot & Roots & Shoot/Roots - Ratio \\
0 & $0.086 \mathrm{aA}$ & $0.042 \mathrm{aA}$ & $2.0 \mathrm{aA}$ \\
100 & $0.060 \mathrm{bA}$ & $0.034 \mathrm{bA}$ & $1.8 \mathrm{bA}$ \\
\hline & & Salt Sensitive & \\
\hline 0 & $0.072 \mathrm{aB}$ & $0.043 \mathrm{aA}$ & $1.7 \mathrm{aB}$ \\
100 & $0.043 \mathrm{bB}$ & $0.030 \mathrm{bA}$ & $1.4 \mathrm{bB}$ \\
\hline
\end{tabular}

${ }^{1}$ Means, followed by the same small letter (between $\mathrm{NaCl}$ treatment, in each genotype) and by the same capital letter (between genotypes, in each $\mathrm{NaCl}$ treatment) for each plant part does not statistically differ by Tukey's test at $5 \%$. The means are average of six different experiments. 
Before salt treatment, the seedling root length of the sensitive genotype $(17.0 \mathrm{~cm})$ was, on average, $36 \%$ larger than the one of the tolerant genotype $(12.5 \mathrm{~cm})$. This difference between genotypes increased in the control plants with time and at the end of the experiment it was about $45 \%$ (Table 2). After seven days of treatment with 100 $\mathrm{mM} \mathrm{NaCl}$ there was a 9.7 and $12.3 \%$ reduction in the final length of the root system of the tolerant and sensitive genotypes, respectively (Table 2). It is interesting to observe that the reductions in the dry matter yields were always much higher (Table 1) than the reductions in root system length, similar to results observed in other species (Cramer et al., 1989).

The length of the stem and of the first internode, on the other hand, also turned out to be much more sensitive to the salt stress than the length of the roots and, in both cases, the sensitive genotype showed reductions much more stronger than the tolerant one (Table 2).

\section{Effect of Salinity on the Ion Transfer Rates to the Shoot}

The $\mathrm{Na}^{+}$and $\mathrm{Cl}^{-}$transfer rates to the shoot, during the experimental period of 0 to 4 days, low in the control plants, increased an average of about five times with the saline treatment in both genotypes (Table 3). The sensitive genotype under salt stress always showed these ion transfer rates significantly higher than the tolerant genotype. In the second experimental period, between 4 and 8 days, it was also observed a strong increase in the ion transfer rates due to salt stress but there was no significant difference between genotypes, although the highest $\mathrm{Na}^{+}$and $\mathrm{Cl}^{-}$concentrations were found in the shoot of the sensitive genotype on the eighth day after the beginning of treatment (data not presented). The smaller $\mathrm{Na}^{+}$ and $\mathrm{Cl}^{-}$transfer rates shown by the tolerant genotype under salt stress at the first experimental period experimental is probably connected to a better control of the root system absorption of these ions (Greenway and Munns, 1980), a higher salt retention in the roots (Salim and Pitman, 1983), a stronger retranslocation of these ions to the roots via phloem, a higher root efflux of these ions, particularly of $\mathrm{Na}^{+}$, to the external solution (Lessani and Marschner, 1978), and, or a higher shoot/roots ratio (Moya et al., 1999) in this genotype.

TABLE 2 - Effect of $\mathrm{NaCl}$ treatment on the length of the roots, of the stems and of the first internode in two sorghum genotypes.

\begin{tabular}{cccc}
\hline $\mathrm{NaCl}(\mathrm{mM})$ & Length $^{1}(\mathrm{~cm})$ \\
\hline & Salt Tolerant \\
\hline & Roots & Stems & $1^{\text {st }}$ Internode \\
0 & $21.8 \mathrm{aB}$ & $3.8 \mathrm{aA}$ & $1.1 \mathrm{aA}$ \\
100 & $19.7 \mathrm{bB}$ & $3.1 \mathrm{bA}$ & $0.7 \mathrm{bA}$ \\
\hline 0 & & Salt Sensitive & $1.0 \mathrm{aB}$ \\
100 & $31.7 \mathrm{aA}$ & $3.5 \mathrm{aB}$ & $0.4 \mathrm{bB}$ \\
\hline
\end{tabular}

\footnotetext{
${ }^{1}$ Means, followed by the same small letter (between $\mathrm{NaCl}$ treatment, in each genotype) and by the same capital letter
} (between genotypes, in each $\mathrm{NaCl}$ treatment) for each plant part does not statistically differ by Tukey's test at $5 \%$. 
TABLE 3 - Effect of $\mathrm{NaCl}$ treatment on ion transfer rates to shoot in two sorghum genotypes.

\begin{tabular}{|c|c|c|c|c|c|c|}
\hline \multirow[b]{2}{*}{ Genotypes } & \multirow{2}{*}{$\begin{array}{l}\mathrm{NaCl} \\
(\mathrm{mM})\end{array}$} & \multicolumn{5}{|c|}{$\begin{array}{c}\text { Ion transfer rates } \\
\left(\mathrm{mmol} \mathrm{kg}^{-1} \text { dry mass day }{ }^{-1}\right)\end{array}$} \\
\hline & & $\mathrm{Cl}^{-}$ & $\mathrm{Na}^{+}$ & $\mathrm{K}^{+}$ & $\mathrm{Ca}^{2+}$ & $\mathrm{Mg}^{2+}$ \\
\hline & & \multicolumn{5}{|c|}{ Period: 0 to 4 days } \\
\hline \multirow{2}{*}{ Salt Tolerant } & 0 & $99.8 \mathrm{bA}$ & $68.7 \mathrm{bA}$ & $663.3 \mathrm{aA}$ & $94.4 \mathrm{aB}$ & $66.1 \mathrm{aB}$ \\
\hline & 100 & $342.5 \mathrm{aB}$ & $380.8 \mathrm{aB}$ & $240.0 \mathrm{bA}$ & $71.3 \mathrm{bB}$ & $57.8 \mathrm{bB}$ \\
\hline \multirow{3}{*}{ Salt Sensitive } & 0 & $105.5 \mathrm{bA}$ & $79.3 \mathrm{bA}$ & $561.1 \mathrm{aB}$ & $143.8 \mathrm{aA}$ & $88.8 \mathrm{aA}$ \\
\hline & 100 & $451.8 \mathrm{aA}$ & $523.5 \mathrm{aA}$ & $138.9 \mathrm{bB}$ & $78.6 \mathrm{bA}$ & $75.1 \mathrm{bA}$ \\
\hline & & \multicolumn{5}{|c|}{ Period: 4 to 8 days } \\
\hline \multirow{2}{*}{ Salt tolerant } & 0 & $251.2 \mathrm{bA}$ & $61.7 \mathrm{bA}$ & $725.9 \mathrm{aA}$ & $175.4 \mathrm{aA}$ & $86.5 \mathrm{aA}$ \\
\hline & 100 & $321.7 \mathrm{aA}$ & $276.6 \mathrm{aA}$ & $226.7 \mathrm{bA}$ & $58.6 \mathrm{bA}$ & $54.6 \mathrm{bA}$ \\
\hline \multirow{2}{*}{ Salt sensitive } & 0 & $164.3 \mathrm{bB}$ & $45.8 \mathrm{bA}$ & $464.3 \mathrm{aB}$ & $169.3 \mathrm{aA}$ & $72.5 \mathrm{aB}$ \\
\hline & 100 & $294.7 \mathrm{aA}$ & $248.6 \mathrm{aA}$ & $112.8 \mathrm{bB}$ & $57.2 \mathrm{bA}$ & $50.2 \mathrm{aA}$ \\
\hline
\end{tabular}

${ }^{1}$ Means, followed by the same small letter (between $\mathrm{NaCl}$ treatment, in each genotype) and by the same capital letter (between genotypes, in each $\mathrm{NaCl}$ treatment) for each period of time and inorganic ion does not statistically differ by Tukey's test at $5 \%$.

The $\mathrm{K}^{+}$transfer rate to the shoot in the tolerant genotype was statistically higher at both experimental periods studied, regardless of the treatment applied (Table 3). The salt stress strongly reduced the $\mathrm{K}^{+}$transfer rate to the shoot in both genotypes, in the two studied periods, specially in the sensitive genotype. The smaller $\mathrm{K}^{+}$ transfer to the shoot under saline conditions is probably due to a reduced $\mathrm{K}^{+}$absorption by the roots. The ion $\mathrm{Na}^{+}$seems to compete with $\mathrm{K}^{+}$for the same absorption site in the plasma membrane (Marschner, 1995; Taleisnik and Grunberg, 1994).

In control plants, the $\mathrm{Ca}^{2+}$ and $\mathrm{Mg}^{2+}$ transfer rates to the shoot in the first experimental period were smaller in the tolerant genotype (Table 3). After salt treatment, both ions transfer rates to the shoot were reduced in the two genotypes, specially of $\mathrm{Ca}^{2+}$. Again, the $\mathrm{Ca}^{2+}$ transfer rate reduction in the sensitive genotype $(45.5 \%)$ was much stronger than in the tolerant one $(24.5 \%)$. In the second experimental period these reductions induced by salt treatment were also observed, and they were even more intense in both genotypes. Since the absorption and the translocation of various mineral ions (specially $\mathrm{Ca}^{2+}$ ) to the shoot depend upon the transpiration flux, probably, at least part of these observed reductions could be due to reduced transpiration rates of the $\mathrm{NaCl}$ stressed plants, as suggested by Wolf et al., (1990). These reductions in transfer rates of ions could also be due to a lowering of the root pressure in salt stressed plants (Marschner, 1995). In spite of that, 
however, one can not reject the possibility of an inhibition of the root absorption of these ions by an excess of $\mathrm{Na}^{+}$in the external solution (Cramer et al., 1985).

\section{Effect of Salinity on the Inorganic Solutes Accumulation and Distribution}

The $\mathrm{Na}^{+}$and $\mathrm{Cl}^{-}$contents, which were low in control plants, greatly increased after salt treatment in both genotypes, specially the $\mathrm{Na}^{+}$ content and in the sensitive genotype (Table 4). The highest contents of these ions were found by order in stems plus sheaths, roots, young leaves $\left(2^{\text {nd }}\right.$ leaf starting from the top) and old leaves $\left(3^{\text {rd }}\right.$ and $4^{\text {th }}$ leaves starting from the top). This preferential salt accumulation in the stems plus sheaths region was taken as indicative of a sorghum salt tolerance mechanism quite common in most of glycophytes (Greenway and Munns, 1980). According to this idea tolerant plants would be able to avoid salt accumulation in the leaves by removing it from xylem and retaining and, or accumulating it in stems, sheaths and, or petioles (Jeschke and Wolf, 1988), before reaching the leaves. Besides, these toxic ions could be compartmentalized in specific tissue or cell of the leaf blade (Boursier and Läuchli, 1989). Therefore, it is possible that salt tolerance could be associated to the synchronization between rate of ion transport to the shoot and the capacity to compartmentalize them in different tissues and cells.

The $\mathrm{K}^{+}$contents in control plants, as expected were much higher than that of $\mathrm{Na}^{+}$and $\mathrm{Cl}^{-}$, and drastically reduced after $\mathrm{NaCl}$ treatment (Table 4). These ion contents in the shoot were, in general, higher in the tolerant genotype, but in the roots, in the sensitive genotype, regardless of the treatment. The salt induced reductions in $\mathrm{K}^{+}$ contents were more intense in the sensitive genotype, except in the oldest leaves. These results indicate that the sensitive genotype under salt stress transfers lower amounts of $\mathrm{K}^{+}$to the shoot and it is not capable to maintain an adequate $\mathrm{K}^{+}$ concentration in leaves as does the tolerant genotype. Part of the salt tolerance differences between these genotypes, therefore, may reside in their differences in $\mathrm{K}^{+} / \mathrm{Na}^{+}$selectivity and in the transfer of $\mathrm{K}^{+}$to the shoot, as suggested by Marschner (1995).

The $\mathrm{Ca}^{2+}$ contents in the shoot of the control plants were always higher in the sensitive genotype (Table 4). The application of salt stress, however, resulted in a strong reduction of $\mathrm{Ca}^{2+}$ contents mainly in the shoot of the plants in the sensitive genotype but only in the stems plus sheaths of the tolerant genotype. On average, the sensitive genotype experienced a reduction in $\mathrm{Ca}^{2+}$ contents twice as much than the tolerant genotype. The greatest reductions in the contents of this ion were observed in the stems plus sheaths in both genotypes, specially in the sensitive one. A great decrease in $\mathrm{Ca}^{2+}$ contents were also observed in the young leaves of the sensitive genotype and this could contribute to higher leaf growth inhibition in this genotype (Läuchli et al., 1994). The $\mathrm{Ca}^{2+}$ contents in the roots did not differ between genotypes and salt stress reduced them only in the tolerant genotype.

In general, $\mathrm{Mg}^{2+}$ contents in the sensitive genotype were higher than in the tolerant genotype, regardless of the treatment applied (Table 4). The salt stress caused reduction in $\mathrm{Mg}^{2+}$ contents in the stems plus sheaths in both genotypes, specially in the sensitive one. On the contrary, in the leaf blades $\mathrm{Mg}^{2+}$ contents increased in salt stressed plants of both genotypes. Increase or reduction in $\mathrm{Mg}^{2+}$ contents in leaves caused by excess of salts has been observed in other species (Araújo, 1994; Lutts et al., 1996; Meloni, 1999). In plants of Phaseolus vulgaris and of Vigna unguiculata, under salt stress, it was found a correlation between $\mathrm{Mg}^{2+}$ retention in the stems and petioles and the contents of this ion in the leaves (Araújo, 1994; Lacerda, 1995). In spite of that, the significance of the change in $\mathrm{Mg}^{2+}$ contents during salt stress to plant tolerance is not clear yet.

The $\mathrm{Na}^{+} / \mathrm{K}^{+}$ratio, which was very small in the control plants, increased a lot after the plants were exposed to high levels of $\mathrm{NaCl}$ in the two genotypes, particularly in the sensitive one (Figure 1). This increase took place in all plant parts 
TABLE 4 - Effect of $\mathrm{NaCl}$ treatment on inorganic solutes contents in different plant parts of two sorghum genotypes.

\begin{tabular}{|c|c|c|c|c|}
\hline \multirow{2}{*}{$\begin{array}{l}\mathrm{NaCl} \\
(\mathrm{mM})\end{array}$} & \multicolumn{4}{|c|}{ Inorganic solute contents (mmol kg${ }^{-1}$ dry mass) ${ }^{1}$} \\
\hline & $2^{\text {nd }}$ Leaf & $\begin{array}{l}3^{\text {rd }}-4^{\text {th }} \\
\text { Leaves }\end{array}$ & $\begin{array}{l}\text { Stems plus } \\
\text { sheaths }\end{array}$ & Roots \\
\hline & \multicolumn{4}{|c|}{ Salt tolerant } \\
\hline & \multicolumn{4}{|c|}{$\mathrm{Cl}^{-}$} \\
\hline 0 & $181.4 \mathrm{bA}$ & $173.5 \mathrm{bA}$ & $330.6 \mathrm{bA}$ & $126.7 \mathrm{bA}$ \\
\hline \multirow[t]{2}{*}{100} & $472.8 \mathrm{aB}$ & $358.6 \mathrm{aB}$ & $978.3 \mathrm{aB}$ & $528.2 \mathrm{aB}$ \\
\hline & \multicolumn{4}{|c|}{$\mathrm{Na}^{+}$} \\
\hline 0 & $27.7 \mathrm{bA}$ & $14.8 \mathrm{bA}$ & $26.5 \mathrm{bA}$ & $51.6 \mathrm{bA}$ \\
\hline \multirow[t]{2}{*}{100} & $465.2 \mathrm{aB}$ & $91.3 \mathrm{aB}$ & $1041.3 \mathrm{aB}$ & $698.3 \mathrm{aB}$ \\
\hline & \multicolumn{4}{|c|}{$\mathrm{K}^{+}$} \\
\hline 0 & $1142.7 \mathrm{aA}$ & $693.1 \mathrm{aA}$ & $1270.4 \mathrm{aA}$ & $1165.6 \mathrm{aB}$ \\
\hline \multirow[t]{2}{*}{100} & $601.5 \mathrm{bA}$ & $510.3 \mathrm{bA}$ & $629.0 \mathrm{bA}$ & $644.7 \mathrm{bA}$ \\
\hline & \multicolumn{4}{|c|}{$\mathrm{Ca}^{2+}$} \\
\hline 0 & $76.9 \mathrm{aB}$ & $169.9 \mathrm{aB}$ & $161.1 \mathrm{aB}$ & $58.0 \mathrm{aA}$ \\
\hline \multirow[t]{2}{*}{100} & $70.5 \mathrm{aA}$ & $181.4 \mathrm{aA}$ & $61.0 \mathrm{bA}$ & $45.1 \mathrm{bA}$ \\
\hline & \multicolumn{4}{|c|}{$\mathrm{Mg}^{2+}$} \\
\hline 0 & $88.5 \mathrm{bB}$ & $100.7 \mathrm{bB}$ & $201.9 \mathrm{aB}$ & $127.4 \mathrm{aB}$ \\
\hline \multirow[t]{3}{*}{100} & $112.9 \mathrm{aB}$ & $148.0 \mathrm{aB}$ & $149.1 \mathrm{bA}$ & $102.9 \mathrm{bB}$ \\
\hline & \multicolumn{4}{|c|}{ Salt sensitive } \\
\hline & \multicolumn{4}{|c|}{$\mathrm{Cl}^{-}$} \\
\hline 0 & $198.8 \mathrm{bA}$ & $171.9 \mathrm{bA}$ & $308.7 \mathrm{bA}$ & $120.9 \mathrm{bA}$ \\
\hline \multirow[t]{2}{*}{100} & $575.0 \mathrm{aA}$ & $410.8 \mathrm{aA}$ & $1116.6 \mathrm{aA}$ & $708.4 \mathrm{aA}$ \\
\hline & \multicolumn{4}{|c|}{$\mathrm{Na}^{+}$} \\
\hline 0 & $37.4 \mathrm{bA}$ & $35.9 \mathrm{bA}$ & $49.7 \mathrm{bA}$ & $81.1 \mathrm{bA}$ \\
\hline \multirow[t]{2}{*}{100} & $874.7 \mathrm{aA}$ & $492.9 \mathrm{aA}$ & $1340.6 \mathrm{aA}$ & $876.9 \mathrm{aA}$ \\
\hline & \multicolumn{4}{|c|}{$\mathrm{K}^{+}$} \\
\hline 0 & $1006.8 \mathrm{aB}$ & $533.5 \mathrm{aB}$ & $1092.1 \mathrm{aB}$ & $1300.3 \mathrm{aA}$ \\
\hline \multirow[t]{2}{*}{100} & $510.1 \mathrm{bB}$ & $480.8 \mathrm{bA}$ & $453.7 \mathrm{bB}$ & $670.9 \mathrm{bA}$ \\
\hline & \multicolumn{4}{|c|}{$\mathrm{Ca}^{2+}$} \\
\hline 0 & $125.1 \mathrm{aA}$ & $259.5 \mathrm{aA}$ & $205.1 \mathrm{aA}$ & $63.4 \mathrm{aA}$ \\
\hline \multirow[t]{2}{*}{100} & $73.4 \mathrm{bA}$ & $157.3 \mathrm{bB}$ & $69.1 \mathrm{bA}$ & $54.4 \mathrm{aA}$ \\
\hline & \multicolumn{4}{|c|}{$\mathrm{Mg}^{2+}$} \\
\hline 0 & $117.4 \mathrm{bA}$ & $157.1 \mathrm{bA}$ & $292.0 \mathrm{aA}$ & $164.8 \mathrm{bA}$ \\
\hline 100 & $134.2 \mathrm{aA}$ & $174.3 \mathrm{aA}$ & $152.6 \mathrm{bA}$ & $186.7 \mathrm{aA}$ \\
\hline
\end{tabular}

${ }^{1}$ Means, followed by the same small letter (between $\mathrm{NaCl}$ treatment, in each genotype) and by the same capital letter (between genotypes, in each $\mathrm{NaCl}$ treatment) for each plant part and inorganic ion does not statistically differ by Tukey's test at $5 \%$. 


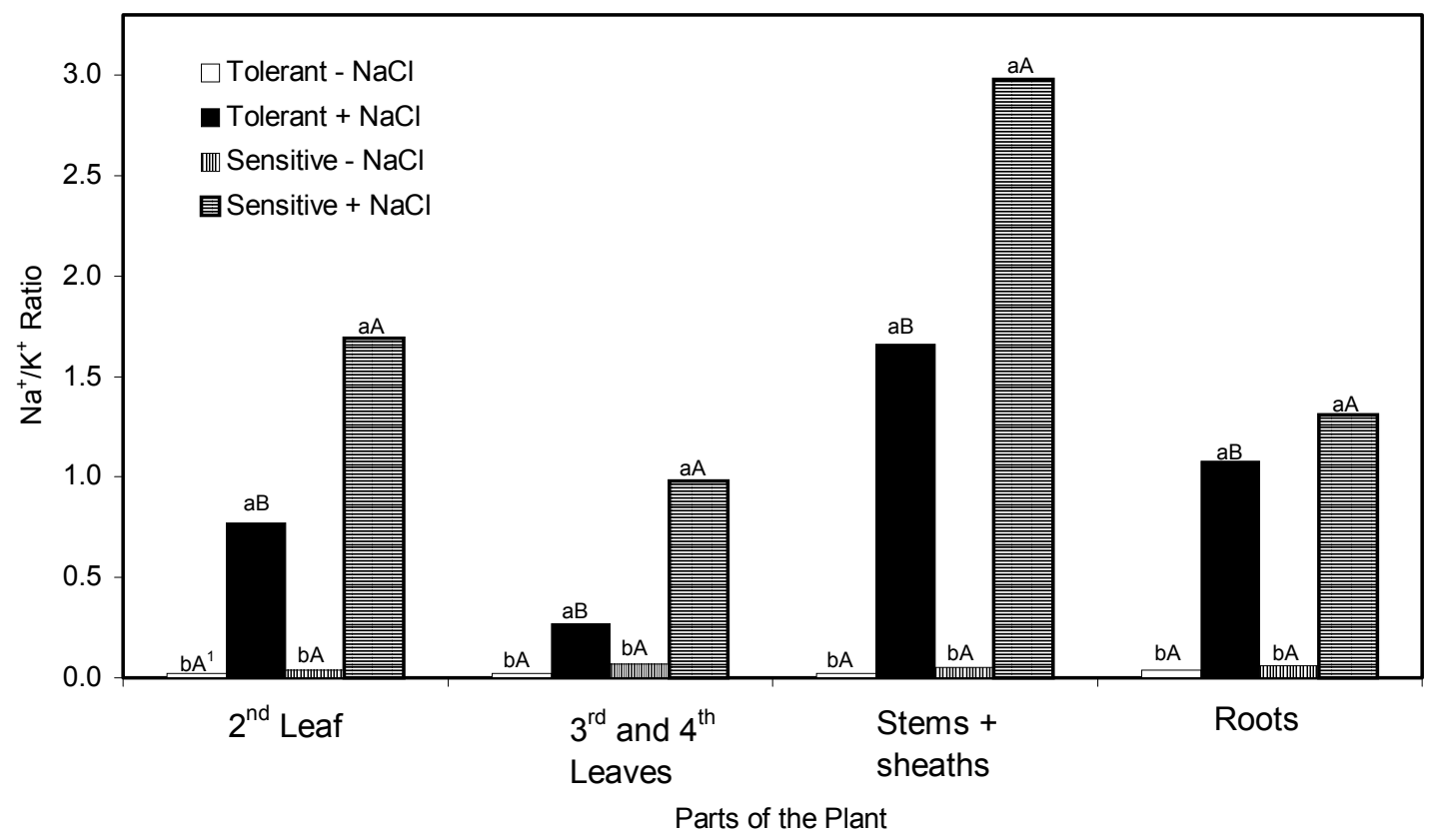

FIGURE 1 - Effect of $\mathrm{NaCl}$ on the $\mathrm{Na}^{+} / \mathrm{K}^{+}$ratio in different plant parts of two sorghum genotypes. ${ }^{1}$ Bars, followed by the same small letter (between $\mathrm{NaCl}$ treatment, in each genotype) and by the same capital letter (between genotypes, in each $\mathrm{NaCl}$ treatment) for each plant part does not statistically differ by Tukey's test at $5 \%$.

studied, but mainly in the stems plus sheaths. In this plant part the $\mathrm{Na}^{+} / \mathrm{K}^{+}$ratio in the sensitive genotype became 1.8 times higher than in the tolerant. It is interesting to observe that, at percent basis, the tolerant genotype under salt stress not only retained more $\mathrm{Na}^{+}$in the stem plus sheaths (Table 4) but also exhibited a smaller reduction in the $\mathrm{K}^{+}$transfer to the shoot (Table 3 ) and maintained higher $\mathrm{K}^{+}$contents in the leaves (Table 4) than the sensitive genotype. Apparently, due these factors, the tolerant genotype was able to maintain a leaf metabolic activity higher than that of the sensitive one.

The total concentration of $\mathrm{Na}^{+}$plus $\mathrm{Cl}^{-}$, which was low in the control plants, increased about 5.5 and 8.2 times, on average, in the tolerant and sensitive genotypes, respectively, with the application of the salt stress (Figure 2). In general, the lowest concentration of these ions occurred in the roots. The maintenance of these low salt concentrations in the root tissues was probably the reason for lower salt induced root growth inhibition comparatively to other plant parts (Tables 1 and 2). It must be emphasized also that this lower salt stress induced reduction on root system growth, may also be due to the maintenance of an adequate transfer of photosynthates to this part of the plants (Curtis and Läuchli, 1986; Taiz and Zeiger, 1998). The concentrations of $\mathrm{Na}^{+}+\mathrm{Cl}^{-}$in the shoot were much greater, particularly in the stems plus sheaths (Figure 2), resulting in a greater reduction in the cell expansion and, also in the growth of these plant parts (Table 2). The highest concentrations of these ions (Figure 2) and the greatest reduction in the stem growth (Table 2) were observed in the sensitive genotype. 


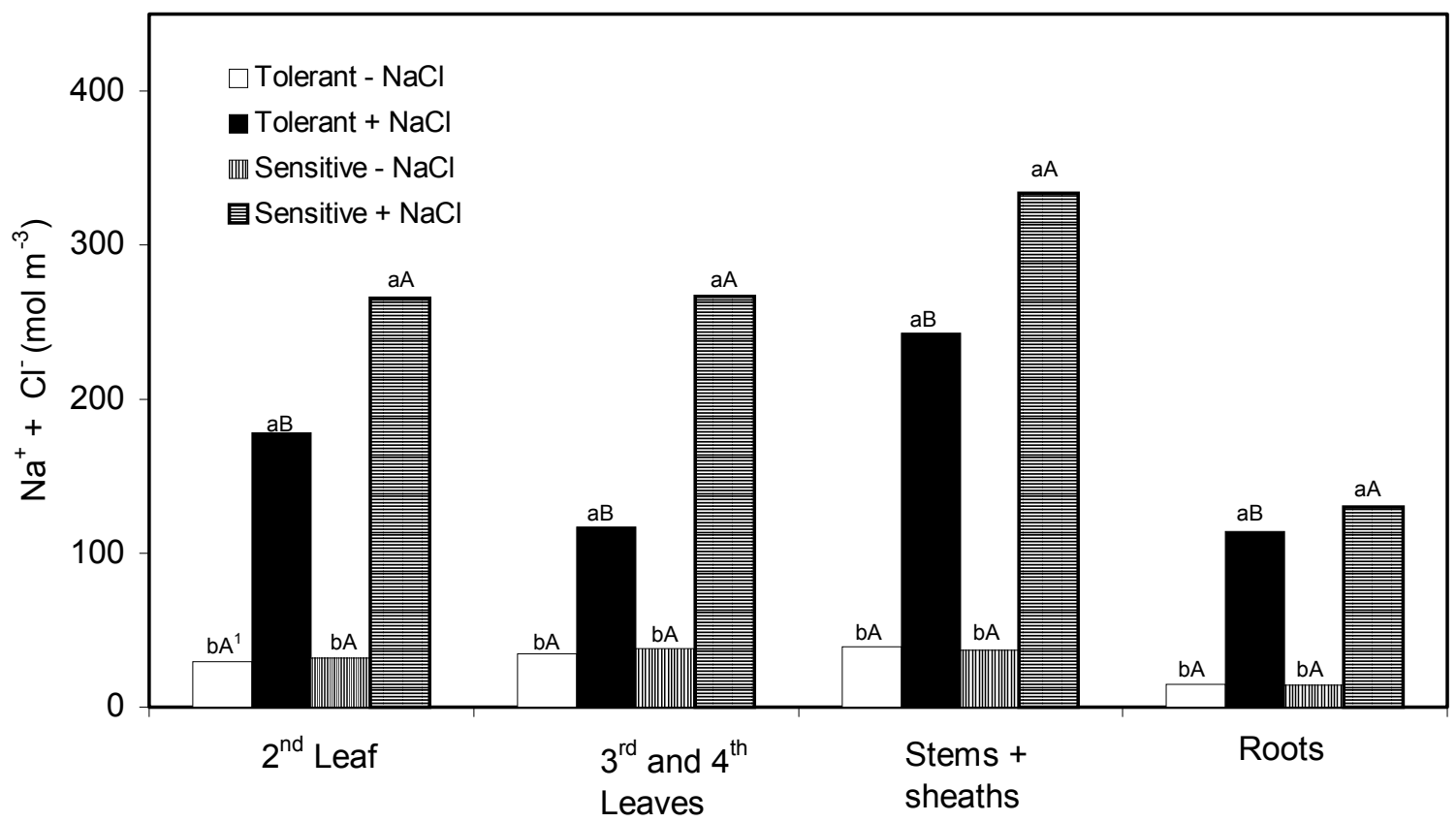

Parts of the Plant

FIGURE 2 - Effect of $\mathrm{NaCl}$ on the $\mathrm{Na}^{+}$plus $\mathrm{Cl}^{-}$concentration in different plant parts of two sorghum genotypes. ${ }^{1}$ Bars, followed by the same small letter (between $\mathrm{NaCl}$ treatment, in each genotype) and by the same capital letter (between genotypes, in each $\mathrm{NaCl}$ treatment) for each plant part does not statistically differ by Tukey's test at $5 \%$.

In general, high $\mathrm{NaCl}$ concentration caused reduction in the plant growth, particularly of the shoot, always with much intensity in the sensitive genotype. Although, the mechanism of salt tolerance remains essentially unknown, the results obtained here indicate that the difference in growth between this two genotypes may be due to differences in ion transfer rates to the shoot and salt accumulation in the shoot. The sensitive genotype showed higher $\mathrm{Na}^{+}$plus $\mathrm{Cl}^{-}$transfer rates to the shoot, specially in the beginning of the stress application (Table 3) and greater accumulation of these ions in the leaves (Table 4). The tolerant genotype, on the other hand, showed higher $\mathrm{K}^{+}$transfer rates and lower relative reduction in the $\mathrm{Ca}^{2+}$ transfer rates to the shoot under salt stress (Table 3), what evidently favored its growth. Additionally, the $\mathrm{Na}^{+} / \mathrm{K}^{+}$ratio was smaller in the tolerant genotype, particularly in the shoot (Figure 1). So, these results suggest that tolerance to salt stress, in this two sorghum genotypes studied here, may be related to plant ability to prevent accumulation of toxic ions like $\mathrm{Na}^{+}$and $\mathrm{Cl}^{-}$and, or to maintain the concentrations of essential ions at adequate levels in the shoot. Plant ability to make adequate osmotic adjustment, however, should not be ignored.

\section{Effect of Salinity on Organic Solutes Accumulation and Distribution}

The proline contents in the control plants were quite low comparatively to other organic solutes, in both sorghum genotypes (Table 5). After salt 
treatment, proline contents increased a lot in all plant parts, specially in the oldest leaves $\left(3^{\text {rd }}\right.$ and $4^{\text {th }}$ leaves starting from the top of the plant) of both genotypes. The salt induced increase in proline contents was always higher in the sensitive genotype than in the tolerant one. The proline contents, even under salt stress, however, did not reach the levels of other organic solutes like carbohydrates and amino acids. It is interesting to observe also that the highest proline content was found in the oldest leaves, which also exhibited the highest levels of leaf salt injury and the lowest fresh/dry matter ratios (data not shown). Similar correlation between proline accumulation and the level of leaf injury was also found in barley and cotton plants under water stress (Hanson et al., 1977; Ferreira et al., 1979) and in soybean plants under salt stress (Moftah and Michel, 1987). In these cases, it was possible to relate the accumulation of proline to water loss in the tissue (Greenway and Munns, 1980).

The betaine contents were quite small in control plants and were not statistically different in the various plant parts of the two genotypes (Table 5). After application of the salt stress there was a rather high relative increase in the contents of this solute, particularly in the youngest leaves. It is interesting to note that, under salt stress conditions, sorghum, barley and wheat seem to be able to synthesize and to accumulate betaine in growing tissues of the shoot, and it has been considered an important organic solute in osmotic adjustment in these plants (Grieve and Maas, 1984; Colmer et al., 1996; Nakamura et al., 1996). However, betaine contents found in this experiment were quite small comparatively to other organic solutes and no difference between the two sorghum genotypes studied here was detected.

On average, carbohydrates and amino acids together constituted more than $98 \%$ of the total of organic solutes determined in the various parts of the plants of the two sorghum genotypes investigated (Table 5). The contents of these organic solutes increased significantly in the presence of $\mathrm{NaCl}$ only in the old leaves $\left(3^{\text {rd }}\right.$ and $4^{\text {th }}$ leaves starting from the top), in the two genotypes.
Among the organic solutes investigated, the soluble carbohydrates showed the highest absolute increase in response to salinity. Similar results have been found in other plant species (Greenway and Munns, 1980; Ashraf, 1994). It is interesting to observe that although the accumulation of total soluble carbohydrates in the old leaves has been greater in the sensitive genotype, the soluble carbohydrate/( $\mathrm{Na}^{+}$plus $\left.\mathrm{Cl}^{-}\right)$ratio in the tolerant genotype (0.93) was much greater than in the sensitive one (0.67). So, the tolerant genotype is able to produce proportionally more carbohydrates for the osmotic adjustment and to maintain adequate conditions for growth under saline environment than the sensitive one. The amino acid contents were high in both genotypes, regardless of presence of $\mathrm{NaCl}$ in the nutrient solution (Table 5). Under salt stress there was an increase in the amino acid contents in the older leaves, specially in sensitive genotype. The highest amino acid contents were found in the roots, specially in the tolerant genotype. Therefore, it is believed that the total soluble carbohydrates were the main organic solutes responsible for the osmotic adjustment in leaves, while the total free amino acids in the roots of plants under saline stress.

Differently from what was found for inorganic solutes, the relationship between accumulation of organic solutes and the tolerance to salt stress was not so clear as with other plant species. For example, the accumulation of organic solutes in leaves, mainly of proline, was greater in the genotype that showed the greatest reduction in growth. Also, the older leaves, exposed to salt stress for longer period of time, exhibited much chlorosis and, or necrosis and visual symptoms of dehydration and higher organic solutes content as well. Apparently, solute accumulation, mainly proline, does not seem to have an important role in the mechanism of salt tolerance, at least for these genotypes and under the experimental conditions applied here. 
Plant growth and solute accumulation and distribution...

TABLE 5 - Effect of $\mathrm{NaCl}$ on organic solutes contents in different plant parts in two sorghum genotypes.

\begin{tabular}{|c|c|c|c|c|}
\hline \multirow{2}{*}{$\begin{array}{l}\mathrm{NaCl} \\
(\mathrm{mM})\end{array}$} & \multicolumn{4}{|c|}{ Organic solutes contents (mmol kg ${ }^{-1}$ dry mass) ${ }^{1}$} \\
\hline & $2^{\text {nd }}$ Leaf & $\begin{array}{l}3^{\text {rd }}-4^{\text {th }} \\
\text { Leaves }\end{array}$ & $\begin{array}{l}\text { Stems plus } \\
\text { sheaths }\end{array}$ & Roots \\
\hline & \multicolumn{4}{|c|}{ Salt tolerant } \\
\hline & \multicolumn{4}{|c|}{ Proline } \\
\hline 0 & $2.1 \mathrm{bA}$ & $2.5 \mathrm{bB}$ & $2.1 \mathrm{bA}$ & $1.9 \mathrm{bB}$ \\
\hline \multirow[t]{2}{*}{100} & $3.0 \mathrm{aB}$ & $15.1 \mathrm{aB}$ & $7.5 \mathrm{aB}$ & $3.1 \mathrm{aB}$ \\
\hline & \multicolumn{4}{|c|}{ Betaine } \\
\hline 0 & $13.8 \mathrm{bA}$ & $11.1 \mathrm{bA}$ & $\mathrm{Nd}^{2}$ & $\mathrm{Nd}$ \\
\hline \multirow[t]{2}{*}{100} & $40.9 \mathrm{aA}$ & $31.9 \mathrm{aA}$ & $\mathrm{Nd}$ & $\mathrm{Nd}$ \\
\hline & \multicolumn{4}{|c|}{ Soluble Carbohydrates } \\
\hline 0 & $204.4 \mathrm{aA}$ & $350.0 \mathrm{bA}$ & $211.1 \mathrm{aB}$ & $163.9 \mathrm{aA}$ \\
\hline \multirow[t]{2}{*}{100} & $188.9 \mathrm{aA}$ & $422.2 \mathrm{aB}$ & $200.0 \mathrm{aA}$ & $198.3 \mathrm{aA}$ \\
\hline & \multicolumn{4}{|c|}{ Amino Acids } \\
\hline 0 & $316.6 \mathrm{aA}$ & $348.7 \mathrm{bA}$ & $\mathrm{Nd}$ & $476.8 \mathrm{bA}$ \\
\hline \multirow[t]{3}{*}{100} & $287.3 \mathrm{aA}$ & $417.8 \mathrm{aB}$ & $\mathrm{Nd}$ & $586.0 \mathrm{aA}$ \\
\hline & \multicolumn{4}{|c|}{ Salt sensitive } \\
\hline & \multicolumn{4}{|c|}{ Proline } \\
\hline 0 & $2.5 \mathrm{bA}$ & $3.1 \mathrm{bA}$ & $2.2 \mathrm{bA}$ & $2.4 \mathrm{bA}$ \\
\hline \multirow[t]{2}{*}{100} & $9.5 \mathrm{aA}$ & $62.8 \mathrm{aA}$ & $21.0 \mathrm{aA}$ & $5.1 \mathrm{aA}$ \\
\hline & \multicolumn{4}{|c|}{ Betaine } \\
\hline 0 & $13.6 \mathrm{bA}$ & $12.3 \mathrm{bA}$ & $\mathrm{Nd}$ & $\mathrm{Nd}$ \\
\hline \multirow[t]{2}{*}{100} & $45.3 \mathrm{aA}$ & $32.3 \mathrm{aA}$ & $\mathrm{Nd}$ & $\mathrm{Nd}$ \\
\hline & \multicolumn{4}{|c|}{ Soluble Carbohydrates } \\
\hline 0 & $200.0 \mathrm{aA}$ & $405.6 \mathrm{bA}$ & $300.0 \mathrm{aA}$ & $163.9 \mathrm{aA}$ \\
\hline \multirow[t]{2}{*}{100} & $173.9 \mathrm{aA}$ & $600.0 \mathrm{aA}$ & $246.7 \mathrm{aA}$ & $192.2 \mathrm{aA}$ \\
\hline & \multicolumn{4}{|c|}{ Amino Acids } \\
\hline 0 & $286.5 \mathrm{aA}$ & $350.1 \mathrm{bA}$ & $\mathrm{Nd}$ & $432.7 \mathrm{aA}$ \\
\hline 100 & $307.5 \mathrm{aA}$ & $496.1 \mathrm{aA}$ & $\mathrm{Nd}$ & $472.0 \mathrm{aB}$ \\
\hline
\end{tabular}

${ }^{1}$ Means, followed by the same small letters (between $\mathrm{NaCl}$ treatment, in each genotype) and by the same capital letters (between genotypes, in each $\mathrm{NaCl}$ treatment) for each plant part and organic solute does not statistically differ by Tukey's test at $5 \% .{ }^{2} \mathrm{Nd}=$ not detected. 


\section{ACKNOWLEDGEMENTS}

The authors acknowledge the financial support given by Fundação de Amparo à Pesquisa do Estado de Minas Gerais (FAPEMIG CRA-2242/97) and fellowships given to the $2^{\text {nd }}$, $3^{\text {rd }}$ and $4^{\text {th }}$ authors by Conselho Nacional de Pesquisa e Desenvolvimento Científico (CNPq). They are thankful to Dr. José Nildo Tabosa (IPAPE) that gently provided the seeds used in this study.

\section{REFERENCES}

ALLAN, J.E. The preparation of agricultural samples for analysis by atomic absorption spectroscopy. Varian Techtron, 1969. 15p. (Boletim 12/69).

ARAÚJO, C.A.S. Avaliação de feijoeiros quanto à tolerância à salinidade em solução nutritiva. Dissertação (Mestrado em Solos e Nutrição de Plantas), Universidade Federal de Viçosa, 1994, 87p.

ASHRAF, M. Organic substances responsible for salt tolerance in Eruca sativa. Biology Plantarum, 26:255-259, 1994.

BATES, L.S.; WALDREN, R.P. AND TEARE, I.D. Rapid determination of free proline for waterstress studies. Plant and Soil, 39:205-207, 1973.

BOURSIER, P. AND LÄUCHLI, A. Mechanisms of chloride partitioning in the leaves of saltstressed Sorghum bicolor L. Physiologia Plantarum, 77:537-544, 1989.

CLARK, R.B. Characterization of phosphatase of intact maize roots. Journal of Agricultural and Food Chemistry, 23:458-460. 1975.

COLMER, T.D., EPSTEIN, E. and DEVORAK, J. Differential solute regulation in leaf blades of various ages in salt sensitive wheat and salt tolerant wheat $\mathrm{x}$ Lophopyron elongation (host) A. love amphiploid. Plant Physiology, 108:1715-1724, 1995.
CRAMER, G.; LÄUCHLI, A. AND POLITO, V.S. Displacement of $\mathrm{Ca}^{2+}$ by $\mathrm{Na}^{+}$from the plasmalemma of root cells. Plant Physiology, 79:207-211, 1985.

CRAMER, G.; EPSTEIN, E. AND LÄUCHLI, A. $\mathrm{Na}-\mathrm{Ca}$ interactions in barley seedlings: relationship to ion transport and growth. Plant, Cell and Environment, 12:551-558, 1989.

CURTIS, P.S. AND LÄUCHLI, A. The role of leaf area development and photosynthetic capacity in determining growth of kenaf under moderate salt stress. Australian Journal of Plant Physiology , 13:553-565, 1986.

FERREIRA, L.G.R.; SOUZA, J.G. AND PRISCO, J.T. Effects of water deficit on proline accumulation and growth of two cotton genotypes of differing drought resistance. $\mathbf{Z}$. Pflanzenphysiologie, 93:189-199, 1979.

GAINES, T.P.; PARKER, M.B. AND GASCHO, G.J. Automated determination of chlorides in soil and plant tissue by sodium nitrate. Agronomy Journal, 76:371-374, 1984.

GREENWAY, H. AND MUNNS, R. Mechanisms of salt tolerance in nonhalophytes. Annual Review of Plant Physiology, 31:149-190, 1980.

GRIEVE, C.M. AND MAAS, E.V. Betaine accumulation in salt-stressed sorghum. Physiologia Plantarum, 61:167-171, 1984.

HANSON, A.; NELSEN, C.E. AND EVERSON, E.H. Evaluation of free proline accumulation as an index of drought resistance using two contrasting barley cultivars. Crop Science, 17:720-726, 1977.

HODGE, J.E. AND HOFREITER, B.T. Determination of reducing sugars and carbohydrates. In: Whistler, R.L. and Wolfrom, M.L. (eds.) Methods in Carbohydrate Chemistry. New York, Academic Press, v. 1, p. 380-394, 1962. 
HORWITZ, W. (ed.) Official methods of analysis of the Association of Official Analytical Chemist. Washington, AOAC, p. 46-47, 1975.

JESCHKE, W.D. AND WOLF, O. Effect of $\mathrm{NaCl}$ salinity on growth, development, ion distribution, and ion translocation in castor bean (Ricinus communis L.). Journal of Plant Physiology, 132:45-53, 1988.

LACERDA, C.F. Efeitos da salinidade no desenvolvimento e composição mineral do feijão-de-corda (Vigna unguiculata (L.) Walp.) e utilização do $\mathrm{Ca}^{2+}$ como meio para minorar tais efeitos. Dissertação (Mestrado em Solos e Nutrição de Plantas), Universidade Federal do Ceará, 1995, 87p.

LÄUCHLI, A., COLMER, T.D., FAN, T.W., HIGASHI, R.M. Solute regulation by calcium in salt-stressed plants. In: CHERRY, J.H. (ed.) Biochemical and cellular mechanisms of stress tolerance in plants. NATO ASI Series, H86:443-461, 1994.

LESSANI, H. AND MARSCHNER, H. Relation between salt tolerance and long-distance transport of sodium and chloride in various crop species. Australian Journal of Plant Physiology, 5:27-37, 1978.

LUTTS, S.; KINET, J.M. AND BOUHARMONT, J. Effects of salt stress on growth, mineral nutrition and proline accumulation in relation to osmotic adjustment in rice (Oryza sativa L.) cultivars differing in salinity resistance. Plant Growth Regulation, 19:207-218, 1996.

MAGGIO, A., BRESSAN, R.A., HAEGAWA, P.M., LOCY, R.D. Moderately increased constitutive proline does not alter osmotic stress tolerance. Physiologia Plantarum, 101:240-246, 1997.

MARSCHNER, H. Mineral nutrition of higher plants. $2^{\text {nd }}$ ed., London, Academic Press, 1995,889 p.
MELONI, D.A. Composição mineral, relações hídricas, atividade fotossintética e crescimento em dois cultivares de algodoeiro submetidos a estresse salino. Dissertação (Mestrado em Fisiologia Vegetal), Universidade Federal de Viçosa, 1999, 48p.

MOORE, S. AND STEIN, W.H. A modified ninhydrin reagent for the photometric determination of amino acids and related compounds. Journal of Biological Chemistry, 176:376-381, 1948.

MOYA, J.L.; PRIMO-MILLO, E. AND TALON, M. Morphological factors determining salt tolerance in citrus seedlings: the shoot to root ratio modulates passive root uptake of chloride ions and their accumulation in leaves. Plant, Cell and Environment, 22:14251433, 1999.

MUNNS, R. AND TERMAAT, A. Whole-plant responses to salinity. Australian Journal of Plant Physiology, 13:143-160, 1986.

NAKAMURA, T., ISHITANI, M., HARINASUT, P., NOMURA, M., TAKABE, T. and TAKABE, T. Distribution of glycinebetaine in old and young leaf blades of salt-stressed barley plants. Plant Cell Physiology, 37:873877. 1996.

SALIM, M. AND PITMAN, M.G. Effects of salinity on ion uptake and growth of mung bean plants (Vigna radiata L.). Australian Journal of Plant Physiology, 10:395-407, 1983.

SHANNON, M.C.; GRIEVE, C.M. AND FRANCOIS, L.E. Whole-plant response to salinity. In: WILKINSON, R.E. (ed.) Plantenvironmental interactions. New York, Marcel-Decker, p. 199-244, 1994.

SERRANO, R. AND GAXIOLA, R. Microbial models and salt stress tolerance in plants. Critical Review in Plant Sciences, 13:121138, 1994. 
TAIZ, L. AND ZEIGER, E. Plant Physiology. Massachusetts, Sinauer Associates, 1998, 792p.

TALEISNIK, E. AND GRUNBERG, K. Ion balance in tomato cultivars differing in salt tolerance. I. Sodium and potassium accumulation and fluxes under moderate salinity. Physiologia Plantarum, 92:528-534, 1994.

WEIMBERG, R.; LERNER, H.R. AND POLJAKOFF-MAYBER, A. Changes in growth and water soluble concentration in Sorghum bicolor stressed with sodium and potassium salts. Physiologia Plantarum, 55:5-10. 1982.

WOLF, O.; MUNNS, R.; TONNET, M.L. AND JESCHKE, W.D. Concentrations and transport of solutes in xylem and phloem along the axis of NaCl-treated Hordeum vulgare. Journal of Experimental Botany, 43:1133-1141, 1990. 